\title{
ANALISIS PENGEMBANGAN MODEL MATAKULIAH PRAKTIK PADA PROGRAM STUDI ILMU PEMERINTAHAN UNIVERSITAS TERBUKA
}

\author{
Siti Aisyah \\ Enceng \\ Universitas Terbuka \\ e-mail: aisyah@ut.ac.id
}

\begin{abstract}
The problem in developing practical courses at universities that apply the distance education in Indonesia are: 1)It is difficult to determine the place of practice for students because students are spread in different locations; 2)The study program found it difficult to develop a practice course in distance education methods. The development of subject matter practice in the government science study program at Universitas Terbuka has a significant urgency with the needs of the people in Indonesia. This article aims to analyze the development of practical courses in government science study programs, in Universitas Terbuka. This article is the result of a research with a qualitative approach. Primary data obtained from interviews with experts, students, and graduate users. Secondary data includes the results of the literature review, the results of previous studies, and documents relating to practical subjects. The research findings are: 1)Mastery of students in understanding governance as science and art implies not only at the level of mastery of theory and concepts, but also the importance of prioritizing attitude skills and behavior in dealing with government phenomena. 2)The subject matter which has the potential to be developed into practice material is a course related to development, village government, the legislature, and the methodology of governmental science. The implication of this finding is the need to conduct a comparative study in the application of practical subjects at several other universities that use distance learning methods both domestically and abroad.
\end{abstract}

Keywords: development, courses, practice, government

\section{PENDAHULUAN}

Program Studi IImu Pemerintahan (PSIPEM) merupakan salah satu program studi yang ada di lingkungan Fakultas IImu Sosial dan IImu Politik Ubuversitas Terbuka (FISIP-UT) yang didirikan berdasarkan ijin operasional Direktur Jenderal Pendidikan Tinggi (Dikti) Nomor 251/DIKTI/Kep/1996. Penyelenggaraan pembelajaran PS IPEM dimulai pada tahun 1999. PS IPEM adalah program studi yang menyelenggarakan pendidikan di bidang ilmu pemerintahan pada jenjang Strata 1 dengan menggunakan model pembelajaran jarak jauh. PS IPEM berada di bawah naungan Jurusan IImu Administrasi FISIP-UT.

Berdasarkan data yang ada, salah satu tujuan PS IPEM FISIP UT adalah menghasilkan lulusan yang menguasai dasar-dasar ilmu pemerintahan sehingga mampu berpikir secara ilmiah; dasar-dasar metodologi ilmu pemerintahan sehingga mampu mengembangkan ilmu pemerintahan; menerapkan dasar ilmu dan metodologi ilmu pemerintahan untuk menyelesaikan masalah-masalah di bidang pemerintahan dengan memanfatkan ilmu pengetahuan dan teknologi. Sedangkan 
kompetensi yang diharapkan dari lulusan S1 PS IImu Pemerintahan adalah kemampuan analisis dalam menerapkan konsep dan teori di bidang pemerintahan untuk mengatasi masalah-masalah masyarakat dengan praktik-praktik good governance.

IImu Pemerintahan pada hakikatnya adalah ilmu yang mempelajari gejala-gejala pemerintahan, yang meliputi hubungan antara yang memerintah dan yang diperintah. Tujuan dan kompetensi program studi ilmu pemerintahan yang dirumuskan tersebut belum selaras dengan esensi ilmu pemerintahan. Selain itu, kurikulum yang diterapkan oleh PS IImu Pemerintahan belum sesuai dengan arah pencapaian standard Kerangka Kualifikasi Nasional Indonesia (KKNI), yang ditetapkan dengan Peraturan Presiden Nomor 8 Tahun 2012. Peraturan tersebut mengisyaratkan standar pencapaian kompetensi yang dinyatakan dalam capaian pembelajaran. Capaian pembelajaran adalah kemampuan yang diperoleh melalui internalisasi pengetahuan, sikap, keterampilan, kompetensi, dan akumulasi pengalaman kerja.

Dalam kenyataannya, kurikulum yang diterapkan oleh PS IImu Pemerintahan adalah kurikulum tunggal. Beban studi mahasiswa PS IPEM ditetapkan sebesar 145 sks, yang tersebar dalam 34 (102 sks) matakuliah utama, 13 matakuliah pendukung (39 sks), dan Tugas Akhir Program (TAP). TAP mempunyai bobot 4 sks, terdiri dari Tugas Akhir Program (4 sks) dan Karya Ilmiah (0 sks). Kurikulum PS IImu Pemerintahan tidak mempersyaratkan praktik atau praktikum. Selain itu, kurikulum PS IImu Pemerintahan juga tidak mempersyaratkan skripsi. Tugas Akhir Program dalam praktiknya berbentuk ujian uraian (essay), yang esensinya terdiri dari beberapa matakuliah yang dianggap sebagai matakuliah core dari keseluruhan matakuliah yang diajarkan dalam kurikulum PS Ilmu Pemerintahan.

Keseluruhan matakuliah yang ada di PS IPEM FISIP-UT adalah murni matakuliah yang berbentuk uraian teori, konsep dan pengetahuan dan belum ada matakuliah yang mensyaratkan praktik. Struktur kurikulum tersebut kurang mendukung pencapaian kualifikasi lulusan program studi sarjana seperti diatur dalam Keputusan Menteri Pendidikan Nasional Republik Indonesia Nomor 232/U/2000, khususnya pada pentingnya lulusan dalam menguasai kemampuan untuk menerapkan ilmu pengetahuan dan keterampilan yang dimilikinya sesuai dengan bidang keahliannya dalam kegiatan produktif dan pelayanan kepada masyarakat dengan sikap dan perilaku yang sesuai dengan tata kehidupan bersama. Selain itu, matakuliah yang mempunyai substansi praktikum/praktik merupakan salah satu instrumen penilaian Borang PS (Instrumen 5.14).

Penelitian ini bertujuan menganalisis tujuan dan kompetensi PS IImu Pemerintahan, serta mengembangkan kemungkinan materi praktik pada salah satu matakuliah pada PS IImu Pemerintahan. Penelitian ini menggunakan pendekatan kualitatif. Pengumpulan data dilakukan dengan metode wawancara mendalam dengan para informan dan studi dokumentasi yang dianggap terkait dan relevan dengan penelitian. Penentuan informan dilaksanakan dengan teknik purposive sampling yang meliputi pakar Ilmu Pemerintahan, pakar bahasa Indonesia, Kepala Unit Pelayanan Belajar Jarak Jauh Universitas Terbuka (UPBJJ-UT) dan pihak-pihak yang terkait dengan pengembangan materi praktik matakuliah pada PS IImu Pemerintahan. Keseluruhan data yang dianalisis untuk diberikan pemaknaan dengan berdasarkan pada pendekatan interpretative social science.

\section{HASIL DAN PEMBAHASAN}

Kurikulum yang diterapkan oleh PS IImu Pemerintahan saat ini adalah kurikulum yang dirumuskan pada tahun 2009. Kurikulum tersebut merujuk pada Keputusan Menteri Pendidikan Nasional Republik Indonesia Nomor 232/U/2000 tentang Pedoman Penyusunan Kurikulum 
Pendidikan Tinggi Dan Penilaian Hasil Belajar Mahasiswa. Menurut peraturan tersebut, pendidikan program sarjana diarahkan pada hasil lulusan yang memiliki kualifikasi sebagai berikut:

a. menguasai dasar-dasar ilmiah dan ketrampilan dalam bidang keahlian tertentu sehingga mampu menemukan, memahami, menjelaskan, dan merumuskan cara penyelesaian masalah yang ada di dalam kawasan keahliannya.

b. mampu menerapkan ilmu pengetahuan dan keterampilan yang dimilikinya sesuai dengan bidang keahliannya dalam kegiatan produktif dan pelayanan kepada masyarakat dengan sikap dan perilaku yang sesuai dengan tata kehidupan bersama.

c. mampu bersikap dan berperilaku dalam membawakan diri berkarya di bidang keahliannya maupun dalam berkehidupan bersama di masyarakat; serta

d. mampu mengikuti perkembangan ilmu pengetahuan, teknologi, dan/atau kesenian yang merupakan keahliannya.

Peraturan tersebut menjadi acuan dalam menetapkan tujuan program studi, kompetensi lulusan, dan penjabaran kurikulum program studi. Namun dalam praktiknya, perumusan tujuan program studi dan kompetensi lulusan belum sesuai dengan esensi ilmu pemerintahan.

\section{Esensi IImu Pemerintahan}

Van Poelje (1953) mendefinisikan ilmu pemerintahan sebagai ilmu yang mengajarkan bagaimana dinas umum disusun dan dipimpin dengan sebaik-baiknya. U. Rosenthal (dalam Labolo: 2008:9) memberikan batasan ilmu pemerintahan sebagai ilmu yang menggeluti studi tentang kinerja internal serta eksternal dari struktur-struktur dan proses-proses pemerintahan umum. Brasz mendefinisikan ilmu pemerintahan sebagai ilmu yang mempelajari tentang cara bagaimana dinas pemerintahan/pelayanan umum itu disusun dan difungsikan baik secara ke dalam maupun ke luar terhadap para warganya. Sedangkan Sadu Wasistiono mendefinisikan ilmu pemerintahan sebagai ilmu yang mempelajari hubungan antara negara dan rakyatnya dalam kontek kewenangan dan pelayanan publik. Singkatnya ilmu pemerintahan adalah ilmu yang mempelajari gejala pemerintahan, yaitu gejala yang berkaitan dengan organisasi serta berfungsinya dinas pemerintahan umum di dalam semua aspeknya, baik ke dalam maupun keluar di dalam kerangka perilaku antara pemerintah dan yang diperintah.

Selain sebagai ilmu yang mandiri, pemerintahan sering dikatakan sebagai seni (art). Ndraha (2003) mengatakan bahwa Imu pemerintahan adalah ilmu yang mempelajari hubungan antara pemerintah dengan yang diperintah dalam kerangka mensejahterakan masyarakat. Dalam mensejahterakan masyarakat pemerintah menyelenggarakan kepemimpinan pembuatan kebijakan, memberikan pelayanan, dengan berlandaskan pada azas, etika, dan ekologi. Oleh karena itu, pemerintahan dapat dikatakan sebagai seni memerintah.

Berdasarkan uraian tersebut, dapat dikatakan bahwa ilmu pemerintahan adalah ilmu yang mempelajari gejala pemerintahan. Gejala pemerintahan adalah peristiwa-peristiwa pemerintahan yang timbul dari hubungan antara pemerintah dengan yang diperintah, yang dapat diidentifikasi memimpin, mengatur, merencanakan, membina, mengurus, melayani, membuat keputusan, melaksanakan, mengamankan, membangun, memberdayakan, dan mengomunikasikan berbagai hal yang berkaitan antara yang memerintah dan yang diperintah. Oleh karena itulah pemerintahan sering dikatakan sebagai seni memerintah.

Uraian mengenai pengertian ilmu pemerintahan tersebut di atas menjadi dasar dalam merumuskan kompetensi hasil pembelajaran bagi institusi yang menyelanggarakan pendidikan tentang pemerintahan, termasuk PS IImu Pemerintahan FISIP-UT. Berkaitan dengan hal itu, maka 
uraian di bawah ini akan menganalisis mengenai kompetensi umum dan khusus yang diharapkan dari lulusan serta tujuan dari PS IImu Pemerintahan FISIP-UT.

\section{Analisis Kompetensi Dan Tujuan PS IImu Pemerintahan}

PS IImu Pemerintahan FISIP-UT yang menyelenggarakan pendidikan S1 di bidang pemerintahan sejak tahun 1996. Dalam Katalog Kurikulum Program Non Pendas Universitas Terbuka 2015 dinyatakan visi, misi, tujuan PS dan kompetensi yang diharapkan dari lulusan PS IPEM. Visi PS IPEM yang diturunkan dari visi UT dinyatakan sebagai

“Menjadi program studi ilmu pemerintahan terunggul di Indonesia pada tahun 2015 dan terunggul di dunia pada tahun 2021 dengan model pembelajaran terbuka jarak jauh "

Sedangkan misi PS IPEM-FISIP UT dinyatakan sebagai berikut:

1. Menyelenggarakan pendidikan dan pengajaran tingkat sarjana bidang IImu Pemerintahan dengan sistem pembelajaran terbuka jarak jauh yang bisa diikuti oleh semua orang;

2. Menyelenggarakan penelitian keilmuan dan terapan bidang IImu Pemerintahan untuk memperkuat disiplin IImu Pemerintahan dan memberikan sumbangan praktis kepada penyelenggara pemerintahan;

3. Menjalin kerja sama dengan institusi dalam dan luar negeri untuk mengembangkan IImu Pemerintahan sebagai disiplin ilmu yang ilmiah dan aplikatif;

4. Menyelenggarakan pengabdian kepada masyarakat dengan cara bermitra dengan pemerintah, pemerintah daerah, dan alumni;

5. Menciptakan materi pembelajaran (cetak, audio, audio-visual, dan materi terunggah di internet) yang berstandar internasional sebagai materi utama dan pendukung dalam sistem pembelajaran jarak jauh;

6. Mengembangkan model e-learning IImu Pemerintahan untuk meningkatkan kualitas pembelajaran jarak jauh;

7. Meningkatkan layanan tutorial onlineyang sudah ada untuk meningkatkan kualitas pembelajaran jarak jauh.

Tujuan Program PS IImu Pemerintahan FISIP-UT dinyatakan sebagai berikut:

1. Menghasilkan sarjana IImu Pemerintahan yang menguasai konsep dan teori ilmu pemerintahan sebagai dasar berperilaku ilmiah baik dalam sikap maupun dalam mengembangkan ilmu pemerintahan;

2. Menghasilkan sarjana Ilmu Pemerintahan yang dapat mengimplementasikan konsep dan teori IImu Pemerintahan dalam kegiatan pemerintahan dan memecahkan masalah yang terjadi di dalamnya;

3. Menghasilkan karya ilmiah hasil penelitian hibah bersaing, penelitian strategi nasional, tulisan di jurnal terakreditasi, dan buku ilmiah yang diterbitkan oleh penerbit nasional;

4. Menghasilkan buku panduan untuk pengabdian kepada masyarakat;

5. Menghasilkan buku materi pokok berstandar internasional PTJJ sesuai dengan tuntutan kurikulum yang berlaku dengan konten sesuai dengan perkembangan ilmu pengetahuan dan teknologi mutakhir; 
6. Menghasilkan materi pembelajaran dalam bentuk audio/audio-visual dan materi pembelajaran yang dapat diunggah, dan download di internet untuk mempermudah mahasiswa memahami materi yang tersaji dalam buku materi pokok;

7. Menghasilkan model e-learning ilmu pemerintahan yang dapat diikuti oleh semua mahasiswa secara mudah;

8. Menghasilkan model tutorial online yang makin mudah diakses oleh mahasiswa sebagai wahana konsultasi dan diskusi mahasiswa dengan dosen/tutor secara jarak jauh.

Berdasarkan uraian dari tujuan PS IImu Pemerintahan, maka dapat dilihat bahwasannya rumusan tujuan program studi masih terlihat kurang memperhatikan pandangan pemerintahan sebagai ilmu yang mandiri dan pemerintahan sebagai seni (art). Menurut pakar ilmu pemerintahan dan ahli bahasa Indonesia tujuan yang dirumuskan tersebut masih bercampur aduk dengan metode, cara pembelajaran, dan strategi yang digunakan oleh institusi pembelajaran. Strategi merupakan bagaimana melaksanakan sesuatu dan petunjuk dalam mencapai tujuan (Ermaya S: 2013).

Selain itu menurut Siregar dan Nara (2010) dalam Suparman (2012:69) menyatakan tujuan pembelajaran khususnya pembelajaran berbasis kompetensi adalah menciptakan tamatan yang kompeten dan cerdas dalam membangun identitas budaya dan bangsanya. Kompetensi yang dikembangkan berupa ketrampilan dan keahlian bertahan hidup dalam perubahan, pertentangan, ketidakmenentuan, ketidakpastian,dan kerumitan-kerumitan dalam kehidupan.

Berkaitan dengan kompetensi, Freden (2003) menjelaskan kompetensi sebagai kemampuan mengerjakan apa yang perlu dilakukan pada saat berhubungan kerja secara produktif dengan orang lain dan lingkungan mereka. Suparman (2012) menjelaskan lebih lanjut pengertian kompetensi sebagai kinerja yang ditunjukkan oleh kemampuan dari hasil menggunakan pengetahuan, keterampilan dan sikap perilaku.

Untuk memperjelas analisis tentang ujuan program studi ilmu pemerintahan perhatikan Tabel 1.

Tabel 1. Analisis dari Tujuan PS IPEM

\begin{tabular}{|c|c|c|}
\hline Tujuan PS IPEM & Hasil Analisis & Dasar Teori \\
\hline $\begin{array}{l}\text { Menghasilkan sarjana Ilmu Pemerintahan yang } \\
\text { menguasai konsep dan teori ilmu pemerintahan } \\
\text { sebagai dasar berperilaku ilmiah baik dalam sikap } \\
\text { maupun dalam mengembangkan ilmu pemerintahan; }\end{array}$ & 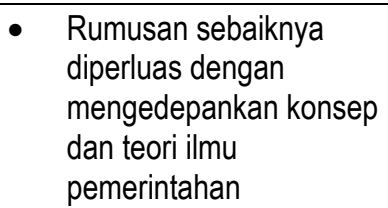 & $\begin{array}{l}\text { Defenisi ilmu pemerintahan } \\
\text { van Poelje, Mc Iver (1985), } \\
\text { Brass, dan Waisitiono }\end{array}$ \\
\hline $\begin{array}{l}\text { Menghasilkan sarjana IImu Pemerintahan yang } \\
\text { dapat mengimplementasikan konsep dan teori IImu } \\
\text { Pemerintahan dalam kegiatan pemerintahan dan } \\
\text { memecahkan masalah yang terjadi di dalamnya; }\end{array}$ & $\begin{array}{l}\text { Konsep dan teori tidak } \\
\text { tepat diimplementasikan } \\
\text { namun diterapkan atau } \\
\text { diaplikasikan } \\
\text { - Implementasi lebih } \\
\text { kepada pelaksanaan } \\
\text { kebijakan atau program } \\
\text { yang sudah } \\
\text { direncanakan }\end{array}$ & $\begin{array}{l}\text { - Defenisi implementasi } \\
\text { Kamus Bahasa } \\
\text { Indonesia, Yus Badudu }\end{array}$ \\
\hline
\end{tabular}


Tabel 1. Lanjutan

Menghasilkan karya ilmiah hasil penelitian hibah bersaing, penelitian strategi nasional, tulisan di jurnal terakreditasi, dan buku ilmiah yang diterbitkan oleh penerbit nasional;

Menghasilkan buku panduan untuk pengabdian kepada masyarakat;

Menghasilkan buku materi pokok berstandar internasional PTJJ sesuai dengan tuntutan kurikulum yang berlaku dengan konten sesuai dengan perkembangan ilmu pengetahuan dan teknologi mutakhir;

Menghasilkan materi pembelajaran dalam bentuk audio/audio-visual dan materi pembelajaran yang dapat diunggah, dan download di internet untuk mempermudah mahasiswa memahami materi yang tersaji dalam buku materi pokok;

Menghasilkan model e-learning ilmu pemerintahan yang dapat diikuti oleh semua mahasiswa secara mudah

Menghasilkan model tutorial online yang makin mudah diakses oleh mahasiswa sebagai wahana konsultasi dan diskusi mahasiswa dengan dosen/tutor secara jarak jauh.
- Bagian dari strategi PS.

- Tujuan program pembelajaran adalah menciptakan tamatan yang kompeten dan cerdas

\author{
Defenisi tujuan \\ pembelajaran Siregar dan \\ Nara (2010:67) dan defenisi \\ strategi (Ermaya.S :2013)
}

Idem Idem Idem Defenisi tujuan pembelajaran Siregar dan Nara (2010:67) dan defenisi strategi (Ermaya.S :2013)

Sumber: Hasil FGD dengan pakar

Berdasarkan analisa pada Tabel 1, maka tujuan PS IImu Pemerintahan disarankan menjadi:

"Tujuan Program Studi IImu Pemerintahan FISIP UT adalah menghasilkan lulusan yang kompeten di bidang pemerintahan melalui program pembelajaran jarak jauh"

Selain tujuan program studi, uraian berikut akan menganalisis kompetensi yang dirumuskan oleh PS IPEM FISIP-UT. Berdasarkan data, rumusan kompetensi umum dan khusus adalah sebagai berikut:

Kompetensi Umum Lulusan PS IImu Pemerintahan FISIP-UT:

Lulusan S1 program studi Ilmu Pemerintahan mampu menganalisis gejala-gejala pemerintahan yang meliputi hubungan antara yang memerintah dan yang diperintah berdasarkan konsep dan teori ilmu pemerintahan. 
Kompetensi Khusus:

1. Mampu menjelaskan konsep-konsep dan teori yang menjadi landasan ilmu pemerintahan;

2. Mampu menerapkan pengetahuan dan keahlian dalam bidang ilmu pemerintahan;

3. Mampu menerapkan prinsip-prinsip good governance dalam penyelenggaraan pemerintahan;

4. Mampu melakukan penelitian dibidang pemerintahan;

5. Menganalisis masalah-masalah kehidupan sosial yang berkembang dalam masyarakat.

Tabel 2 berusaha menjelaskan Analisis Kompetensi Umum dan Khusus pada PS IPEMFISIP UT.

Tabel 2. Analisis Kompetensi Lulusan PS IPEM

\begin{tabular}{lll}
\hline Kompetensi & Hasil Analisis & Dasar Teori/Alasan \\
\hline Umum: & Analisis: & Pemerintahan dapat \\
Lulusan S1 program studi Ilmu & Pemerintahan sebagai & dipandang sebagai \\
Pemerintahan mampu menganalisis & ilmu dan seni. & ilmu dan seni. \\
masalah-masalah dibidang pemerintahan & Perlu ditambahkan: & (Mc Iver (1985), van \\
dan kemasyarakatan berdasarkan konsep & menerapkan ilmu & Poelje, Brass, dan \\
dan teori ilmu pemerintahan. & pemerintahan & Waisitiono. \\
& Konsep dan teori dihapus & Ilmu pemerintahan \\
& & adalah ilmu yang \\
& & mempelajari gejala- \\
& & gejala pemerintahan \\
& & (ilmu dan seni). \\
\hline
\end{tabular}

Kompetensi Khusus

Khusus:

Mampu menjelaskan konsep-konsep dan teori yang menjadi landasan ilmu pemerintahan;

Mampu menerapkan pengetahuan dan keahlian dalam bidang ilmu pemerintahan;

Mampu menerapkan prinsip-prinsip good governance dalam penyelenggaraan pemerintahan;

Mampu melakukan penelitian dibidang pemerintahan;

Menganalisis masalah-masalah kehidupan sosial yang berkembang dalam masyarakat
- IImu pemerintah mempelajari gejala-
Defenisi IImu gejala pemerintahan.
Pemerintahan Robert
- Perlu ditingkatkan Mc Iver(1985), Van menjadi analisis
Poelje, dan Brass

Aplikasi ilmu pemerintahan Defenisi pemerintahan dalam hidup bermasyarakat Tujuan tsb sebaiknya dihapus, karena good governance hanya merupakan salah satu paradigma dalam ilmu pemerintahan

Cukup

Defenisi pemerintahan

No. 5 sudah tercakup dalam no.2 
Tujuan pembelajaran dan kompetensi sebaiknya dirumuskan secara selaras. Oleh karena itu, berdasarkan diskusi dengan pakar pemerintahan dan ahli bahasa Indonesia, maka rekomendasi rumusan kompetensi umum dan khusus adalah

Kompetensi Umum:

Lulusan S1 IImu Pemerintahan FISIP-UT mampu mengaplikasikan konsep

dan teori pemerintahan terhadap gejala-gejala pemerintahan

Sedangkan kompetensi khusus merupakan penjabaran dari kompetensi umum, yang rekomendasinya adalah sebagai berikut:

Kompetensi Khusus Lulusan PS IImu Pemerintahan

1. Mampu menganalisis gejala-gejala pemerintahan berdasarkan teori dan konsep pemerintahan.

2. Mampu menerapkan teori dan konsep pemerintahan dalam kehidupan sosial dan bermasyarakat

3. Mampu menghasilkan karya ilmiah di bidang pemerintahan

\section{PENGEMBANGAN MODEL PRAKTIK PADA MATAKULIAH IPEM4542 PEMBANGUNAN MASYARAKAT DESA DAN KOTA}

Sesuai dengan Keputusan Menteri Pendidikan Nasional Republik Indonesia Nomor 232/U/2000 tentang Pedoman Penyusunan Kurikulum Pendidikan Tinggi Dan Penilaian Hasil Belajar Mahasiswa, pendidikan program sarjana diarahkan pada hasil lulusan yang memiliki kualifikasi sebagai berikut:

a. menguasai dasar-dasar ilmiah dan keterampilan dalam bidang keahlian tertentu sehingga mampu menemukan, memahami, menjelaskan, dan merumuskan cara penyelesaian masalah yang ada di dalam kawasan keahliannya;

b. mampu menerapkan ilmu pengetahuan dan keterampilan yang dimilikinya sesuai dengan bidang keahliannya dalam kegiatan produktif dan pelayanan kepada masyarakat dengan sikap dan perilaku yang sesuai dengan tata kehidupan bersama;

c. mampu bersikap dan berperilaku dalam membawakan diri berkarya di bidang keahliannya maupun dalam berkehidupan bersama di masyarakat; serta

d. mampu mengikuti perkembangan ilmu pengetahuan, teknologi, dan/atau kesenian yang merupakan keahliannya.

Berdasarkan ketentuan tersebut, PS IPEM FISIP UT perlu mengembangkan beberapa matakuliah praktik untuk menunjang capaian pembelajaran yang diharapkan. Untuk dapat melaksanakan praktik dibutuhkan laboratorium yang berfungsi menunjang praktikum. Dalam kaitannya dengan pentingnya laboratorium sebagai salah satu komponen penunjang dalam melaksanakan program pembelajaran. Suparman (2012) menjelaskan bahwa laboratorium tidak hanya terbatas yang berada dalam ruang tertutup. IImu sosial banyak membutuhkan laboratorium yang berada di lapangan, di lingkungan masyarakat. Di berbagai instansi pemerintah dan perusahaan. Peserta didik ilmu politik, hukum dan sejarah, misalnya perlu menyaksikan rapat-rapat 
DPR-DPRD, penyelenggaraan pengadilan dan kunjungan ke museum. Kerjasama antara pengajar, pengelola laboratorium, serta pengelolaan satuan pendidikan, sangat diperlukan untuk lebih menjamin tercapainya tujuan pembelajaran.

Pemikiran tersebut menunjukkan pentingnya matakuliah praktik untuk menunjang capaian pembelajaran yang berbasis kompetensi. Menurut pakar ilmu pemerintahan, pengembangan matakuliah berpraktik pada kurikulum PS IImu Pemerintahan sangat dimungkinkan. Tabel 3 merupakan hasil resume dari diskusi dengan pakar ilmu pemerintahan.

Tabel 3. Kemungkinan Pengembangan Matakuliah Praktik pada PS IPEM

\begin{tabular}{|c|c|c|c|}
\hline Matakuliah & Materi Praktik & Lokasi/laboratorium & Kompetensi \\
\hline $\begin{array}{l}\text { IPEM4542 } \\
\text { Pembangunan } \\
\text { Masyarakat Desa dan } \\
\text { Kota }\end{array}$ & $\begin{array}{l}\text { Perencanaan dalam } \\
\text { pembangunan, } \\
\text { Musyawarah } \\
\text { Perencanaan } \\
\text { Pembangunan } \\
\text { (Musrenbang) }\end{array}$ & $\begin{array}{l}\text { Kantor Kelurahan/Desa, } \\
\text { Kantor Kecamatan }\end{array}$ & $\begin{array}{l}\text { Menyusun rencana } \\
\text { pembangunan desa } \\
\text { berdasarkan teori }\end{array}$ \\
\hline $\begin{array}{l}\text { IPEM4208 Sistem } \\
\text { Pemerintahan Desa }\end{array}$ & $\begin{array}{l}\text { Administrasi } \\
\text { pemerintahan } \\
\text { desa/kelurahan }\end{array}$ & Kantor Kelurahan/Desa & $\begin{array}{l}\text { Menyusun, } \\
\text { mengkoordinasikan, } \\
\text { mengomunikasikan } \\
\text { administrasi } \\
\text { pemerintahan desa } \\
\text { atau kelurahan }\end{array}$ \\
\hline $\begin{array}{l}\text { IPEM4323 Legislatif } \\
\text { Indonesia }\end{array}$ & Peraturan Daerah & $\begin{array}{l}\text { Kantor DPRD } \\
\text { kabupaten/Kota }\end{array}$ & $\begin{array}{l}\text { Menyusun, } \\
\text { menganalisis, dan } \\
\text { mengevaluasi } \\
\text { peraturan daerah } \\
\text { sebagai bagian dari } \\
\text { kebijakan publik }\end{array}$ \\
\hline $\begin{array}{l}\text { IPEM4207 Metodologi } \\
\text { IImu Pemerintahan }\end{array}$ & Proposal Penelitian & $\begin{array}{l}\text { Instansi pemerintah dan } \\
\text { lembaga } \\
\text { kemasyarakatan }\end{array}$ & $\begin{array}{l}\text { Membuat proposal } \\
\text { penelitian } \\
\text { pemerintahan }\end{array}$ \\
\hline
\end{tabular}

Sumber: Hasil Analisis, 2015.

Berpijak dari hasil diskusi dengan pakar pemerintahan tersebut, pengembangan matakuliah berpraktik pada PS IImu Pemerintahan FISIP-UT penelitian ini merekomendasikan praktik matakuliah pada matakuliah IPEM4542 Pembangunan Masyarakat Desa dan Kota. Adapun alasan pemilihan matakuliah tersebut adalah selain matakuliah tersebut pernah dikembangkan pada program Continue Education (CE) yang berbasis praktik dengan segmen aparatur desa (Sekdes), juga kemungkinan kemudahan dalam melaksanakan praktik di beberapa lokasi praktik di kantor instansi pemerintah, antara lain: Di Kantor Kelurahan/Desa, Kantor Kecamatan atau Kantor Badan Perencanaan Pembangunan Daerah (Bappeda). Tabel 4 adalah model rancangan pengembangan praktik pada matakuliah IPEM4542 Pembangunan Masyarakat Desa dan Kota. 
Tabel 4. Rancangan Pengembangan Materi Praktik pada Matakuliah IPEM4542 Pembangunan Masyarakat Desa dan Kota.

\begin{tabular}{|c|c|c|c|c|}
\hline $\begin{array}{l}\text { KOMPETENSI } \\
\text { UMUM }\end{array}$ & $\begin{array}{l}\text { KOMPETENSI } \\
\text { KHUSUS }\end{array}$ & $\begin{array}{c}\text { ASPEK } \\
\text { PENILAIAN }\end{array}$ & FOKUS PENILAIAN & BENTUK TUGAS \\
\hline $\begin{array}{l}\text { Mahasiswa } \\
\text { mampu } \\
\text { mendiskripsikan } \\
\text { kegiatan } \\
\text { perencanaan } \\
\text { pembangunan } \\
\text { berdasarkan teori }\end{array}$ & $\begin{array}{l}\text { Mahasiswa mampu: } \\
\text { 1. Menjelaskan teori } \\
\text { pembangunan } \\
\text { 2. Mengaplikasikan } \\
\text { kegiatan } \\
\text { perencanaan } \\
\text { pembangunan } \\
\text { berdasarkan teori } \\
\text { pembangunan }\end{array}$ & $\begin{array}{l}\text { 1. Penguasaan teori } \\
\text { 2. Diskripsi Kegiatan } \\
\text { Pembangunan } \\
\text { berdasarkan teori }\end{array}$ & $\begin{array}{l}\text { Kualitas penjabaran } \\
\text { tulisan dalam } \\
\text { menerapkan teori } \\
\text { Pembangunan dalam } \\
\text { kegiatan perencanaan } \\
\text { pembangunan }\end{array}$ & $\begin{array}{l}\text { 1. Membuat diskripsi } \\
\text { kegiatan Perencanaan } \\
\text { Pembangunan } \\
\text { desa/kelurahan di } \\
\text { tempat Anda tinggal } \\
\text { dan analisislah } \\
\text { dengan teori } \\
\text { pembangunan yang } \\
\text { Anda ketahui } \\
\text { 2. Mempresentasikan } \\
\text { hasil rangkuman di } \\
\text { depan kelas. }\end{array}$ \\
\hline
\end{tabular}

Sumber: Hasil Diskusi dengan pakar dan BMP IPEM4542 Pembangunan Masyarakat Desa dan Kota

Berkaitan dengan tuntutan KKNI, PS IImu Pemerintahan FISIP-UT perlu menerapkan metode pembelajaran praktik. Metode ini merupakan sebuah metode pembelajaran dimana mahasiswa melaksanakan kegiatan latihan atau praktik atau pengalaman praktik agar memiliki keterampilan yang lebih tinggi dari teori yang telah dipelajari. Metode pembelajaran praktik dapat meningkatkan kemampuan mahasiswa dalam mengaplikasikan pengetahuan dan keterampilan yang diperolehnya. Kegiatan ini dilakukan di lapangan, yang bisa berarti di tempat kerja maupun di masyarakat. Praktik merupakan upaya untuk memberi kesempatan kepada mahasiswa untuk mendapatkan pengalaman langsung. Ide dasar belajar berdasarkan pengalaman, mendorong mahasiswa untuk merefleksi atau melihat kembali pengalaman-pengalaman yang pernah mereka alami. Selama praktik, mahasiswa diharapkan mampu melihat, mengamati, memahami, membandingkan dan memecahkan suatu masalah saat kegiatan praktik dilaksanakan.

Praktik merupakan suatu pelaksanaan dari teori dalam keadaan nyata, suatu bentuk pendidikan dengan cara memberikan pengalaman belajar bagi mahasiswa untuk berpartisipasi dengan tugas langsung di Lembaga BUMN, BUMD, Perusahaan Swasta, dan Instansi Pemerintahan setempat. Praktik akan menambah kemampuan untuk mengamati, mengkaji serta menilai antara teori dengan kenyataan yang terjadi di lapangan yang pada akhirnya dapat meningkatkan kualitas managerial mahasiswa dalam mengamati permasalahan dan persoalan, baik dalam bentuk aplikasi teori maupun kenyataan yang sebenarnya. Melalui praktik, mahasiswa akan mengenal dan mengetahui secara langsung tentang instansi sebagai salah satu penerapan disiplin dan pengembangan karier. Ketika di lapangan melaksanakan praktik, mahasiswa dapat menilai tentang pengembangan dari ilmu yang mereka miliki; mahasiswa akan memperoleh wawasan tentang dunia kerja yang diperoleh di lapangan. Mahasiswa akan merasakan secara langsung perbedaan antara teori di kelas dengan yang ada di lapangan. Praktik sangat membantu mahasiswa dalam meningkatkan pengalaman kerja sehingga dapat menjadi tenaga kerja profesional nantinya. Praktik menjadi media pengaplikasian dari teori yang diperoleh dari bangku kuliah ke tempat kerja. Melalui praktik, mahasiswa akan lebih dapat memahami konsep-konsep non-akademis di dunia kerja. Praktik akan memberikan pendidikan berupa etika kerja, disiplin, kerja keras, profesionalitas, dan lain-lain. Di samping itu, melalui praktik akan meningkatkan hubungan kerjasama antara perguruan tinggi dengan instansi. Praktik dapat menjadi media promosi lembaga terhadap institusi kerja. Kualitas lembaga 
perguruan tinggi dapat terukur dari kualitas para mahasiswa yang melaksanakan praktik tersebut. Selain itu, dapat membantu institusi kerja untuk mendapatkan tenaga kerja akademis yang sesuai dengan kebutuhan tenaga kerja yang dimilikinya.

Penerapan praktik pada institusi yang menggunakan metode pembelajaran jarak jauh dengan jumlah mahasiswa yang besar dan jangkauan yang luas bukanlah pekerjaan yang mudah. Beberapa aspek yang perlu dipertimbangkan jika Program Studi IImu Pemerintahan akan menerapkan metode pembelajaran praktik sebagaimana diungkapkan oleh narasumber (2015) antara lain:

- Kontrol Kualitas:

Praktik adalah kegiatan yang menuntut mahasiswa untuk menerapkan konsep, prinsip, prosedur, dan keterampilan dalam situasi nyata atau buatan secara terprogram dan terbimbing atau mandiri. Agar kegiatan praktik dapat terjamin kualitasnya, maka pelaksanaan praktik harus dimonitor oleh pengelola program studi atau oleh UPBJJ-UT. Di samping itu, program studi harus mempersiapkan pedoman dan panduan praktik secara komprehensif.

- $\quad$ Sumber Daya Manusia:

Kegiatan praktik dilaksanakan di bawah bimbingan instruktur/supervisor/pembimbing. Hal ini berarti pengelola program studi atau UPBJJ-UT harus mampu menyiapkan sumber daya manusia yang memiliki kompetensi sesuai dengan substansi matakuliah berpraktik tersebut. Penyediaan sumber daya manusia yang kompeten untuk instruktur/supervisor/ pembimbing merupakan tantangan tersendiri bagi UPBJJ-UT.

- Sarana dan Prasarana:

Praktik dilaksanakan di institusi lain sesuai dengan substansi praktik yang memiliki sarana dan prasarana sesuai persyaratan yang ditetapkan program studi dalam pedoman penyelenggaraan praktik. Penyiapan instansi tempat praktik yang memadai menuntut UPBJJ-UT untuk melakukan kerjasama dengan berbagai instansi. Penyediaan sarana dan prasarana yang memadai ini juga berkaitan dengan jumlah mahasiswa yang akan melakukan praktik. Bagi UPBJJ-UT tertentu hal ini mendatangkan kesulitan tersendiri.

- $\quad$ Sistem Evaluasi:

Mata kuliah berpraktik pada Program Studi IImu Pemerintahan adalah mata kuliah yang nilai akhirnya ditentukan oleh nilai praktik dan UAS. Hal ini berarti akan merubah komposisi penilaian terhadap hasil belajar mahasiswa. Di samping itu, Pusat Komputer harus menyesuaikan aplikasi sistem penilaian yang semula hanya ditentukan oleh UAS.

\section{SIMPULAN}

Esensi dari ilmu pemerintahan adalah ilmu yang mempelajari gejala pemerintahan, yaitu gejala yang berkaitan dengan organisasi serta berfungsinya dinas pemerintahan umum di dalam semua aspeknya, baik ke dalam maupun ke luar di dalam kerangka perilaku antara pemerintah dan yang diperintah. Gejala pemerintahan adalah peristiwa-peristiwa pemerintahan yang timbul dari hubungan antara pemerintah dengan yang diperintah, yang dapat diidentifikasi memimpin, mengatur, merencanakan, membina, mengurus, melayani, membuat keputusan, melaksanakan, mengamankan, membangun, memberdayakan, dan mengomunikasikan berbagai hal yang berkaitan antara yang memerintah dan yang diperintah. Oleh karena itulah pemerintahan sering dikatakan sebagai seni memerintah.

Tujuan program studi dan kompetensi lulusan yang diharapkan, yang telah ditetapkan oleh PS IImu Pemerintahan FISIP-UT belum sejalan dengan esensi dari ilmu pemerintahan. Tujuan dan 
kompetensi yang dirumuskan masih bercampur baur dengan metode, cara dan strategi dalam pembelajaran.

Kemungkinan dalam mengembangkan materi praktik untuk menunjang pencapaian kompetensi pada lulusan PS IImu Pemerintahan terbuka luas, yakni dengan memanfaatkan laboratorium di lapangan, seperti instansi pemerintah, kantor kepala desa/kelurahan, DPRD, kantor pemerintah daerah, dan lain sebagainya.

Rancangan pengembangan materi praktik untuk matakuliah IPEM4542 Pembangunan Masyarakat Desa dan Kota difokuskan pada kualitas mahasiswa dalam mendiskripsikan kegiatan perencanaan pembangunan berdasarkan pada teori yang ada.

Praktik menambah kemampuan untuk mengamati, mengkaji serta menilai antara teori dengan kenyataan yang terjadi di lapangan yang pada akhirnya dapat meningkatkan kualitas managerial mahasiswa dalam mengamati permasalahan dan persoalan, baik dalam bentuk aplikasi teori maupun kenyataan yang sebenarnya. Praktik sangat membantu mahasiswa dalam meningkatkan pengalaman kerja sehingga dapat menjadi tenaga kerja profesional. Praktik akan memberikan pendidikan berupa etika kerja, disiplin,kerja keras, profesionalitas, dan lain-lain. Di samping itu, melalui Praktik akan meningkatkan hubungan kerjasama antara perguruan tinggi dengan instansi .

Untuk meningkatkan kualitas program studi, PS IImu Pemerintahan FISIP-UT perlu mengkaji secara terus-menerus perkembangan ilmu pemerintahan, agar dalam menetapkan tujuan dan kompetensi dapat selaras dengan perkembangan ilmu pengetahuan pada umumnya dan ilmu pemerintahan pada khususnya. Selain itu, PS IImu Pemerintahan perlu merumuskan kembali tujuan program studi dan kompetensi lulusan yang diharapkan dengan mendasarkan pada esensi ilmu pemerintahan, serta perlu mengkaji kemungkinan-kemungkinan dalam mengembangkan materi praktik untuk menunjang capaian pembelajaran yang maksimal.

\section{REFERENSI}

Ermaya Suradinata. (2013). Hukum Dasar Geopolitik dan Geostrategi dalam Kerangka Keutuhan NKRI. Jakarta: Suara Bebas.

Freden, Jacob. (2003). Handbook Of Modren Sensor, Physics, Designs, and Applications. Springer San Diego. USA.

Iver. Mc. (1985). Jaring-Jaring Pemerintahan. Terj. Jakarta: Aksara Baru.

Labolo, Muhadam (Ed). (2008). Beberapa Pandangan Dasar tentang IImu Pemerintahan. Malang: Bayumedia Publishing.

Ndraha, Taliziduhu. (2003). Kybernologi (Ilmu Pemerintahan Baru). Jilid 1-2. Rineka Cipta. Jakarta. Poelje, Van G.A. (1953). Pengantar Umum IImu Pemerintahan. Terj. Djakarta: NV Soeroengan. Siregar, Eveline \& Hartini Nara. (2014). Teori Belajar dan Pembelajaran.Bogor: Galia Indonesia. Suparman, M.Atwi. (2012). Desain Instruksional Modern. Jakarta: Penerbit Erlangga.

Suradinata, Ermaya. (2013). Analisis Kepemimpinan. Strategi Pengambilan Keputusan. Jatinangor: Cakrawala Baru Dunia Buku. 